\title{
JEA
}

\section{PENGARUH KUALITAS PENGUNGKAPAN CORPORATE SOCIAL RESPONSIBILITY, DEWAN DIREKSI WANITA DAN DEWAN KOMISARIS WANITA TERHADAP TAX AGGRESSIVE}

\section{(Studi Empiris Perusahaan yang Menerbitkan Laporan Keberlanjutan dan terdaftar di Bursa Efek Indonesia Tahun 2015-2018)}

\author{
Beni Rahman $^{1}$, Charoline Cheisviyanny ${ }^{2}$, \\ ${ }^{1}$ Alumni Jurusan Akuntansi Fakultas Ekonomi Universitas Negeri Padang \\ ${ }^{2}$ Jurusan Akuntansi Fakultas Ekonomi, Universitas Negeri Padang \\ *Korespondensi: benirahman23.ae@gmail.com
}

\begin{abstract}
The objective of this study is to examine the effect of quality of corporate social responsibility disclosures, female board of directors and female board of commissionerss on tax aggressive. The analysis technique used multiple regression analysis methods. The sample for this study consisted of 19 companies listed on the Indonesia stock exchange (BEI) and reported sustainability reports for 2015-2018, so that 76 observations were obtained. The results found that quality of CSR disclosure has no effect on tax aggressive, the female board of directors has no effect on tax aggressive. While the female board of commissioners has negative effect on tax aggressive. Future researches are sugested to focus on each company to get better results.
\end{abstract}

Keywords : Board of commissioners; board of director; quality of the CSR disclosure; tax aggressive

How to cite (APA $6^{\text {th }}$ style):

Rahman, Beni., \& Cheisviyanny, Charoline. (2020). Pengaruh Kualitas Pengungkapan Corporate Social Responsibility, Dewan Direksi Wanita Dan Dewan Komisaris Wanita Terhadap Tax Aggressive (Studi Empiris Perusahaan Yang Menerbitkan Laporan Keberlanjutan Dan Terdaftar Di Bursa Efek Indonesia Tahun 2015-2018). Jurnal Eksplorasi Akuntansi, 2(3), Seri A, 2942-2955.

\section{PENDAHULUAN}

Pajak menurut UU KUP Nomor 28 Tahun 2007 Pasal 1 ayat 1 adalah kontribusi wajib kepada negara yang terutang oleh orang pribadi atau badan yang sifatnya memaksa, dipergunakan untuk keperluan negara bagi sebesar-besarnya kemakmuran rakyat dengan tidak mengharapkan imbalan secara langsung. Pajak wajib dibayarkan oleh wajib pajak, baik wajib pajak pribadi maupun wajib pajak badan. Pajak yang dibayarkan nantinya akan diakui sebagai penerimaan oleh Negara.

Dalam sistem pemungutan pajak, Indonesia menganut sistem Self Assesment. Sistem ini memberikan kesempatan kepada wajib pajak untuk menghitung, membayar dan melaporkan 
sendiri kewajiban perpajakannya. Aturan tentang sistem Self Assesment terdapat dalam pasal 12 UU ketentuan umum perpajakan. Adanya kesempatan yang diberikan oleh pemerintah kepada wajib pajak dalam menghitung dan melaporkan sendiri kewajiban perpajakannya seakan memberikan celah kepada wajib pajak untuk dapat mengurangi jumlah pajak yang mesti dibayar. Dalam penelitian ini penulis akan berfokus pada perusahaan sebagai wajib pajak badan. Kesempatan untuk mengurangi jumlah pajak yang harus dibayar menjadi salah satu cara bagi perusahaan agar laba yang dihasilkan lebih besar nantinya. Menurut Brian dan Martani (2014), dua cara yang dapat dilakukan perusahaan untuk memperkecil jumlah pajak yang dibayar yaitu dengan memperkecil nilai pajak dan ttap mengikuti peraturan perpajakan yang berlaku (penghindaran pajak) atau memperkecil nilai pajak dengan melanggar ketetapan undang undang perpajakan (penggelapan pajak).

Sari dan Martani (2010) mengatakan pajak yang dibayarkan oleh pihak perusahaan kepada negara adalah proses pembagian kekayaan dari pihak perusahaan kepada negara, sehingga pembayaran pajak akan dianggap sebagai biaya oleh pihak perusahaan. Lanis dan Ricardscon (2011) mengatakan bahwa pajak merupakan faktor pendorong dalam banyak keputusuan perusahaan. Dalam penelitiannya juga disebutkan bahwa tindakan manajerial pun dirancang hanya semata-mata untuk meminimalkan pajak, yang mana tindakan tersebut lebih dikenal dengan istilah agresisivitas pajak.

Frank, Lynch, Rego (2009) mendefinisikan agresivitas pajak sebagai tindakan dalam merekayasa penghasilan kena pajak yang dirancang melalui perencanaan pajak, baik itu secara legal (tax avoidance) maupun ilegal (tax evasion). Agresivitas pajak yang dilakukan perusahaan dapat mengurangi beban yang dikeluarkan oleh perusahaan dan meningkatkan kekayaan pemegang saham, oleh karena itu agresivitas pajak dikatakan sebagai tindakan yang tidak bertanggung jawab secara sosial (Hanlon dan Heitzman, 2010). Pajak yang nantinya akan diperuntukkan sebagai sumber pembiayaan dalam pembangunan nasional dan kemakmuran masyarakat. Namun dalam penerimaannya menjadi tidak maksimal dikarnakan adanya tindakan oleh pihak-pihak yang berusaha mngindarai pembayran pajak tersebut. Walau kegiatan perencanaan pajak tidak semua dapat dikatakan melanggar peraturan, tetapi semakin besar dan banyak cara yang digunakan oleh perusahaan dalam penghematan pajak maka perusahaan tersebut dapat dikatakan dalam keadaan agresif terhadap pajak ( Rizky dan Fajdar, 2017 ).

Pada dasarnya perusahaan memiliki kewajiban dan tanggungjawab kepada stakeholder atas seluruh aktivitas yang dilakukan perusahaan. Perusahaan harus selalu menjaga hubungan baik dan memenuhi harapan yang diinginkan oleh stakeholder. Salah satu bentuk pemenuhan hak stakeholder tersebut diantaranya dapat berupa kepatuhan dalam melakukan pembayaran pajak kepada pemerintah sesuai dengan ketentuan yang berlaku. Kemudian dalam menjaga hubungan baik dengan masyarakat selaku stakeholder. Pemerintah mengeluarkan sejumlah aturan bagi perusahaan untuk ikut terjun dalam program Tanggung jawab sosial yang dicanangkan sebagaii komitmen perusahaan untuk ikut serta dalam mencapai pembangunan ekonomi berkelanjutan dalam meningkatkan kualitas kehidupan dan lingkungan yang bermanfaat, baik itu bagi perseroan sendiri, komunitas setempat, maupun masyarakat pada umumnya (UU No.40 Tahun 2007 Pasal 1 ayat 3).

Huseynov dan Klamm (2012) berpendapat bahwa perusahaan yang memiliki hubungan baik dengan masyarakat cenderung untuk tidak melakukan penghindaran pajak, sedangkan perusahaan yang tidak menjaga hubungan baik dengan masyarakat cenderung untuk melakukan penghindaran pajak. Pengungkapan Corporate Social Responsibility (CSR) dianggap sebagai 
salah satu cara untuk membangun kepercayaan dan hubungan baik antara perusahaan dengan para stakeholder (Lanis dan Richardson, 2011).

Beberapa penelitian sebelumnya yang pernah dilakukan mengenai kaitan antara CSR dan Agresivitas pajak diantaranya adalah penelitian Watson (2011) serta Lanis dan Richardson (2012). Watson menguji hubungan CSR dan agresivitas pajak dengan hasil yang menyebutkan bahwa CSR mempunyai efek mengurangi tingkat agresivitas pajak perusahaan. Sementara Lanis dan Richardson (2012) meneliti mengenai hubungan CSR dan agresivitas pajak dengan Effective Tax Rate (ETR) sebagai alat ukur agresivitas, hasilnya menunjukkan semakin tinggi CSR suatu perusahaan, maka semakin rendah agresivitas pajak yang dilakukan. Yoehana (2013) dan Pradnyadari (2015) juga melakukan penelitian serupa dengan menganalisis hubungan antara CSR dengan agresivitas pajak, dan hasilnya mendapati bahwa CSR dan agresivitas pajak saling berkebalikan atau berpengaruh negatif. Semakin tinggi kegiatan dan pengungkapan CSR, maka perusahaan dianggap peduli terhadap lingkungan dan tidak akan melakukan agresivitas pajak. Berbeda dengan penelitian Nusantari, Nuzula \& Darono (2015), Maesarah, Atikah dan Husnaini (2015). Makhfudlah, Herawati dan wulandari (2018) Penelitian ini menemukan bahwa CSR tidak berpengaruh terhadap perencanaan agresivitas pajak.

Agresivitas pajak yang dilakukan oleh perusahaan dalam kenyataanya merupakan suatu keputusan atau hasil yang dibentuk oleh pihak perusahaan sendiri, dan bukan merupakan suatu kebetulan. Indonesia adalah negara dengan struktur dewan perusahaannya menganut sistem twotier sistem, yakni memisahkan peran dan tanggung jawab antara dewan komisaris dan dewan direksi. Dalam peranannya, dewan komisaris dan dewan direksi bertugas sebagai pemberi saran yang membantu perusahaan dan melindungi dari ketidakpastian lingkungan. Dewan komisaris dan dewan direksi juga berperan sebaagi mekanisme internal guna mengontrol manajemen untuk bertindak dan mengambil keputusan sesuaai dengan pemegang saham dan pemilik (young et al, 2001 dalam kusumawati dan riyanto, 2005). Berdasarkan keterangan tersebut mengartikan dewan komisaris dan dewan direksi juga melakukan suatu fungsi pengendalian internal, yang mana dengan melalui upaya administrasi bisa saja memengaruhi efisiensi dari biaya perusahaan, salah satunya biaya (beban) pajak dan juga melakukan pengawasan atau kontrol yang dapat memaksimalkan nilai dari pemegang saham.

Dalam beberapa tahun terakhir, salah satu isu penting yang sering muncul adalah mengenai diversitas anggota dewan komisaris dan direksi. Menurut Luckerath-Rovers (2010) dalam penelitiannya mendefinisikan diversitas dalam konteks corporate governance sebagai suatu komposisi dewan komisaris dan direksi dan kombinasi dari kualitas, karakteristik, serta keahlian yang masing masing berbeda antara individu anggota dewan, dalam kaitannya dengan pengambilan keputusan dan proses lainnya dalam dewan perusahaan termasuk keputusan yang berkaitan dengan hal pajak. Pada penelitian ini Penulis berfokus pada keberadaan dewan direksi wanita dan dewan komisaris wanita sebagai faktor yang mempengaruhi tax aggressive terkait dengan isu gender diversiti yang berkembang. Dalam penelitian Jackson dan Miliron (1986) bahwa gender dapat mempengaruhi kepatuhan wajib pajak yang menunjukkan bahwa wajib pajak wanita lebih patuh dari pada wajib pajak pria.

Penelitian oleh Richardson et al. (2016) menunjukan bahwa relatif terhadap, kehadiran wanita sebagai direksi yang tinggi (lebih dari satu) mengurangi kemungkinan terjadinya agresivitas pajak. Lain hal dengan penelitian Oyenike dan Olaynika (2016) meneliti hubungan antara diversitas gender dewan direksi dan agresivitas pajak perusahaan pada sektor perbankan yang terdaftar di Nigerian Stock Exchange (NSE). Penelitian tersebut menemukan bahwa direktur wanita tidak berpengaruh secara signifikan terhadap tax aggressive perusahaan 
perbankan Nigeria. Sementara itu di Indonesia Rahayu (2016) menunjukan bahwa representasi direktur keuangan wanita berpengaruh secara signifikan terhadap tingkat agresivitas pajak perusahaan.

Penelitian ini dilakukan dengan tujuan menguji pengaruh kualitas pengungkapan Corporate social responcibility, Dewan Direksi Wanita dan Dewan Komisaris Wanita terhadap tax aggressive. Hasil yang belum konsisten dari temuan penelitian terdahulu mengakibatkan peneliti tertarik untuk melakukan pengujian kembali. Hasil penelitian diharapkan dapat memberi kontribusi dalam kajian empiris dan dijadikan perbandingan, pengembangan, dan penyempurnaan dari temuan penelitian-penelitian yang telah pernah dilakukan.

\section{REVIEW LITERATUR DAN PENGEMBANGAN HIPOTESIS \\ Teori stakeholder}

Teori stakeholder adalah teori yang menggambarkan kepada pihak mana saja perusahaan bertanggungjawab (Freeman, 1984). Dalam asumsi teori stakeholder, perusahaan bertanggung jawab tidak hanya kepada shareholder namun juga kepada stakeholder yang ikut menunjang jalannya operasional perusahaan. Pihak eksternal yang dimaksud antara lain pemerintah dan lingkungan sosial. Pemerintah memberikan jaminan perlindungan kepada perusahaan dalam melakukan operasionalnya. Di sisi lain, perusahaan juga harus menjalankan kewajibannya kepada pemerintah seperti membayar pajak sesuai dengan UU. Hubungan perusahaan dengan lingkungan sekitar juga harus terjalin baik agar perusahaan dapat melakukan aktifitas operasioanalnya tanpa ada halangan yang mengganggu atau pemberhentian di tempat perusahaan beroperasi.

\section{Teori Agensi}

Teori agensi didefinisikan oleh Jensen dan Meckling (1976) sebagai suatu hubungan dimana satu pihak yang disebut principle (pemilik perusahaan) memberikan wewenang kepada pihak lain (agent) untuk bertindak atas nama prinsiple dalam otoritas pengambilan keputusan perusahaan. Agen kemudian bertanggung jawab kepada prinsipal atas keputusan keputusan yang diambil.

Teori keagenan menjelaskan bagaimana pihak-pihak dalam perusahaan akan bertindak, yang pada dasarnya masing masing pihak memiliki kepentingan yang berbeda. Pemilik perusahaan selaku prinsiple memiliki tujuan bagaimana perusahaan berkembang dan going concern. Sedang manajer selaku agen memiliki tujuan untuk mendapatkan pengahasilan sebesarbesanya dari perusahaa. Perbedaan tujuan tersebut menimbulkan konflik yang kemudian memunculkan biaya keagenan.

Dalam teori agensi atau keagenan terdapat kesepakatan antara pemilik sumber daya dengan manajer untuk mengelola perusahaan dan mencapai tujuan utama perusahaan yaitu maksimal laba, sehingga kadang kala manajer melakukan berbagai cara untuk mencapai tujuan tersebut baik cara yang baik ataupun cara yang dapat merugikan banyak pihak (Luayyi, 2010).

\section{Teori Nature}

Teori nature mengungkapkan bahwa perbedaan antara pria dan wanita adalah kodrat yang harus diterima. Pria maupun wanita memiliki perbedaan kodrat sesuai perannya masing-masing. Terdapat peran dan tugas yang dapat dipertukarkan, tetapi ada pula yang tidak dapat dipetukarkan karena memang berbeda secara kodrat alamiah (Heffina, 2004). Berbagai penelitian terkait dengan gender menjelaskan bahwa perbedaan gender seseorang akan mempengaruhi perilaku orang tersebut.. Barber dan Odean (2001) dalam Novilia dan Paskah (2016) menunjukkan bahwa wanita cenderung menghindari risiko dibanding pria. Sedangkan Hilda 
(2004) dalam Sihite (2012) berpendapat bahwa kepribadian laki-laki pada umumnya bersifat lebih individualis, agresif, kurang sabar, lebih tegas, dengan rasa percaya diri lebih tinggi dan lebih menguasai pekerjaan.

Dikaitkan dengan tindakan Tax Aggresive, teori ini menjelaskan bahwa pria dan wanita akan memiliki pertimbangan dan tindakan yang berbeda yang mungkin memiliki implikasi yang penting dalam proses meminimalkan pajak yang akan dibayar perusahaan. Sifat wanita yang lebih berhati-hati dibandinng pria, menghindari resiko, dan memiliki standar etika yang lebih tinggi diharap mampu meredam motivasi untuk dilakukannya tax aggresive oleh perusahaan.

\section{Tax Aggressive}

Agresivitas pajak merupakan tindakan yang dilakukan untuk manipulasi nilai pendapatan kena pajak agar beban pajak yang diperoleh lebih kecil dari seharusnya, baik secara legal (tax avoidance) maupun ilegal (tax evasion) (Frank, Lynch, Rego ,2009). Tindakan aggresivitas pajak dipandang sebagai perilaku yang tidak etis oleh masyrakat. Jessica dan Toly (2014) dalam penelitiiannya menyebutkan masyarakat memandang bahwa perusahaan yang melakukan tindakan agresivitas pajak dianggap telah menjalankan suatu kegiatan yang tidak bertanggung jawab secara sosial. Karna pajak yang disetorkan kepada negara nantinya dipergunakan untuk program pembangunan nasional. Jika penerimaan nya tidak maksimal maka akan menghambat jalannya program tersebut. Namun tindakan aggresifitas pajak menjadi tindakan yang biasa dilakukan oleh perusahaan sebagai langkah bijak oleh perusahaan dalam mencapai tujuannya yakni maksimum profit.

\section{Corporate Social Responsiility}

CSR diartikan sebagai kumpulan kebijakan yang terhubung dengan stakeholder, pemenuhan ketentuan hukum, penghargaan masyarakat, lingkungan serta komitmen dunia usaha agar dapat berkontribusi dalam pembangunan berkelanjutan (Siregar 2007). Menurut Anggaraini (2006) CSR adalah mekanisme dari suatu organisasi dalam melakukan aktifitas operasionalnya dengan stakeholder, juga ikut andil dalam mengintegrasikan perhatiannya terhadap lingkungan dan sosial yang melebihi tanggunng jawab di bidang hukum. CSR mendukung perusahaan terlibat dengan para stakeholder dalam penciptaan jangka panjang. Hal ini bukan bermaksud untuk mengkesampingkan dari pentingnya peran para pemegang saham ataupun dari profitabilitas perusahaan. Namun sebaliknya, jika perusahaan ingin tetap bertahan dan menguntungkan, maka perusahaan harus terlibat dengan para stakeholder yang pandangannya mengenai keberhasilan perusahaan sangat bervariasi (Bichta, 2003).

\section{Gender Dewan Direksi Wanita dan Gender Dewan Komisaris Wanita}

Gender adalah konsep yang memandang bahwa ada perbedaan antara laki-laki dengan perempuan dari sudut non biologisnya, contohnya dari aspek budaya, sosial, dan perilaku (Mutmainah, 2007). Unger (1979) dalam (Faramita, 2016) mennjelaskan bahwa pria memiliki sikap maskulin dengan ciri sifat mandiri, rasional, pertimbangan penuh, dan kompetitif sedangkan wanita dengan sifat feminim mempunyai ciri sifat mengayomi, sensitif, penuh perhatian, dan lebih mengandalkan intuisinya.

Gender dalam penelitian ini diproksi berdasarkan keberadaan wanita pada dewan direksi dan keberadaan wanita pada dewan kommisaris. Keberadaan wanita di jajaran dewan menunjukkan bahwa perusahaan memberikan kesempatan yang sama bagi setiap orang untuk menduduki posisi penting di perusahaan tanpa adanya diskriminasi atau membedakan antara laki-laki dan perempuan.Wanita dinilai dengan sikap kehati- hatian yang tinggi, teliti dan 
cendrung menghindari resiko dibanding laki-laki ( kusumastuti, 2006). Dengan adanya wanita pada jajaran dewan direksi dan dewan komisaris, diharapkan mampu meredam motivasi untuk perusahaan melakukan tax aggressive.

\section{Pengembangan Hipotesis \\ Kualitas pengungkapan Corporate Social Responsiility dan Tax Aggresive}

Perusahaan adalah subjek pajak yang memiliki kewajiban unruk membayar pajakn kepada negara. Dengan membayar pajak, perusahaan dinilai telah ikut berpartisipasi dalam hal mencapai cita-cita bangsa. Harari (2012) dalam nugraha ( 2015) menyatakan masyarakat memandang pajak sebagai dividen yang dibayarkan perusahaan kepada masyarakat sebagai imbal jasa atas penggunaan sumber daya yang ada. Oleh karna itu, perusahaan akan dinilai tidak adil oleh masyarakat apabila melakukan penghindaran dalam pembayaran pajaknya. Perusahaan dinilai oleh masyarakat sebagai pihak yang hanya akan mengambil keuntungan sendiri tanpa adanya pemikiran untuk masyarakat dan lingkungan. Hal ini akan mengganggu hubungan antara masyarakat dan perusahaan.

Dalam hal teori stakeholder, perusahaan harus mempertimbangkan semua pihak atas dampak dari aktivitas operasional yang dilakukan. Dengan membayar pajak secara jujur tanpa ada tindakan aggresivitas, perusahaan dinilai telah ikut andil membantu pemerintah dalam mengumpulkan sumber pendanaan dalam mensejahterakan masyarakat. Penelitian oleh Lanis dan Richardson (2012) menunjukkan bahwa semakin tinggi tingkat pengungkapan CSR yang dilakukan perusahaan maka perusahaan akan semakin menjauhi tindakan agresivitas pajak. Karena perusahaan yang mengungkapkan CSR telah berusaha untuk membangun hubungan yang baik dengan stakeholder, baik melalui kegiatan CSR maupun dengan membayar pajak sesuai dengan kewajibannya. Oleh karena itu, hipotesis penelitian ini adalah :

H1: Kualitas pengungkapan CSR berpengaruh Negatif Terhadap Tax Aggresive

\section{Pengaruh Gender Dewan Direksi dan Gender Dewan Komisaris Terhadap Tax Aggressive}

Hadirnya wanita dalam struktur dewan bukanlah sekedar menanggapi dari adanya persoalan kesetaraan gender (Credit Suisse Research Institute 2012). Keberadaan wanita pada jajaran dewan dinilai mempunyai pengaruh terhadap tindakan Tax Aggresive yang terjadi di perusahaan. Penelitian Ricardson (2016) menunjukan bahwa adanya satu atau lebih wanita dalam jajaran dewan direksi berpengaruh signifikan dalam mengurangi tax aggressve perusahaan. Lain hal dalam penelitiaan Oyenike dan Olaynika (2016) meneliti hubungan antara diversitas gender dewan direksi dan agresivitas pajak perusahaan pada sektor perbankan yang terdaftar di Nigerian Stock Exchange (NSE). Dari hasil penelitian tersebut ditemukan bahwa direktur wanita tidak berpengaruh secara signifikan terhadap tindakan tax aggressive di perusahaan perbankan Nigeria.

Selanjutnya penelitian yang menguji tentang pengaruh gender dewan komisaris terhadap tax aggressive oleh Fitritawati (2018) menemukan bahwa keberadaan wanita dalam jajaran dewan komisaris berpengaruh terhadap tax aggressive perusahaan. Berbeda dengan temuan Gunawan (2018) bahwa tidak ada pengaruh keberagaman gender dewan komisaris terhadap aggressive tax planning yang diukur menggunakan ETR perusahaan.

Penelitian oleh Barber dan Odean (2001) dalam Novilia dan Paskah (2016) menyebutkan bahwa wanita cenderung menghindari risiko dibanding pria. Sifat wanita yang lebih berhati-hati dibanding pria, menghindari resiko, dan memiliki standar etika yang lebih tinggi, diharap mampu meredam motivasi untuk melakukan tax aggressive di perusahaan. Adanya wanita pada dewan direksi berguna dalam mengambil keputusan yang tepat dengan risiko yang rendah (Kusumastuti, 
Supatmi, dan Sastra, 2007; Sudana dan Arlindania, 2011) dalam (Eriandani dan Kuswanto, 2016). Begitu pula dengan hadirnya wanita dalam jajaran dewan komisaris, diharapkan juga memiliki tingkat pengawasan yang lebih tinggi dibanding pria. Sehingga mampu meredam keinginan untuk melakukan tax agrressive dalam perusahaan. Oleh karena itu, peneliti mengambil hipotesis: $\mathrm{H} 2 \mathrm{a}$ : Dewan direksi wanita berpengaruh negatif terhadap Tax Aggresive $\mathrm{H} 2 \mathrm{~b}$ : Dewan komisaris wanita berpengaruh negatif terhadap Tax Aggressive

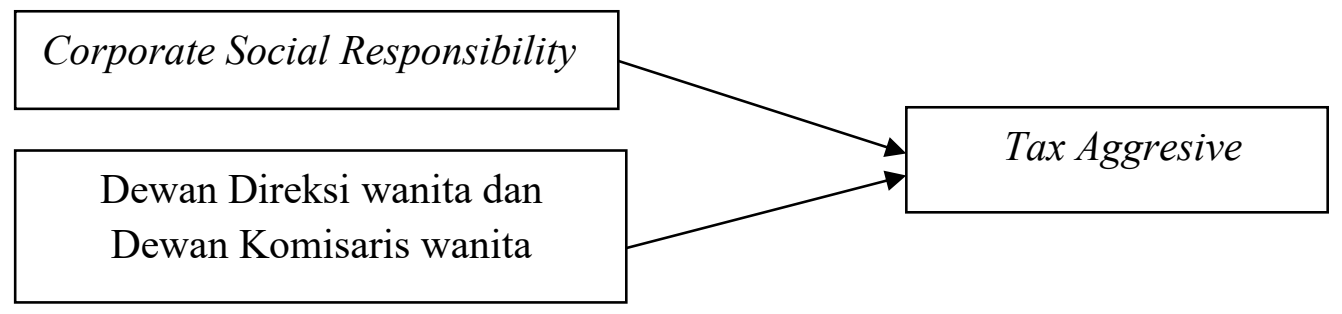

Gambar 1.

Metode Penelitian

Kerangka Konseptual

\section{Populasi dan sampel}

Populasi penelitian ini adalah perusahaan-perusahaan yang menerbitkan sustainability report secara berturut dan terdaftar di Bursa Efek Indonesia (BEI) tahun 2015-2018. Pengambilan sampel diperoleh dengan menggunakan metode purposive sampling. Kriteria sampel penelitian adalah (1) Perusahaan yang terdaftar di Bursa Efek Indonesia periode 2015-2018.(2) Perusahaan yang menyajikan laporan keberlanjutan (subtainability report) secara berturut-turut periode 2015-2018.(3) Perusahaan tidak didelisting selama periode pengumpilan data 2015- 2018. (4) Perusahaan menyajikan laporan keuangan dalam satuan mata uang rupiah. (5) Perusahaan tidak mengalami rugi agar tidak menyebabkan distorsi dalam pengukuran agresivitas pajak.

\section{Tabel 1}

\section{PemilihanSampel}

\begin{tabular}{lc}
\hline \multicolumn{1}{c}{ Kriteria } & Jumlah Perusahaan \\
\hline $\begin{array}{l}\text { Perusahaan yang menerbitkan sustainability } \\
\text { tahun 2015- 2018 }\end{array}$ & 50 \\
$\begin{array}{l}\text { Perusahaan yang tidak menyajikan } \\
\text { secara berturut-turut tahun 2015-2018 }\end{array}$ & $(15)$ \\
$\begin{array}{l}\text { Perusahaan mengalami kerugian } \\
\text { Perusahaan yang menyajikan laporan keuangan selain dalam }\end{array}$ & $(14)$ \\
satuan mata uang rupiah & $(2)$ \\
Jumlah Sampel Penelitian & 19 \\
Jumlah observasi (dikali 3 tahun) & 76 \\
\hline
\end{tabular}

\section{Jenis dan Sumber Data}

Jenis data penelitian ini adalah data sekunder yang dapat diperoleh pada laporan tahunan dan laporan keberlanjutan perusahaan. Sumber data penelitian dapat diunduh di website BEI (www.idx.co.id), website masing-masing perusahaan dan website National Center of Sustainability Reporting (www.ncsr-id.org). 


\section{Tabel 2}

\section{Definisi Variabel dan Pengukuran}

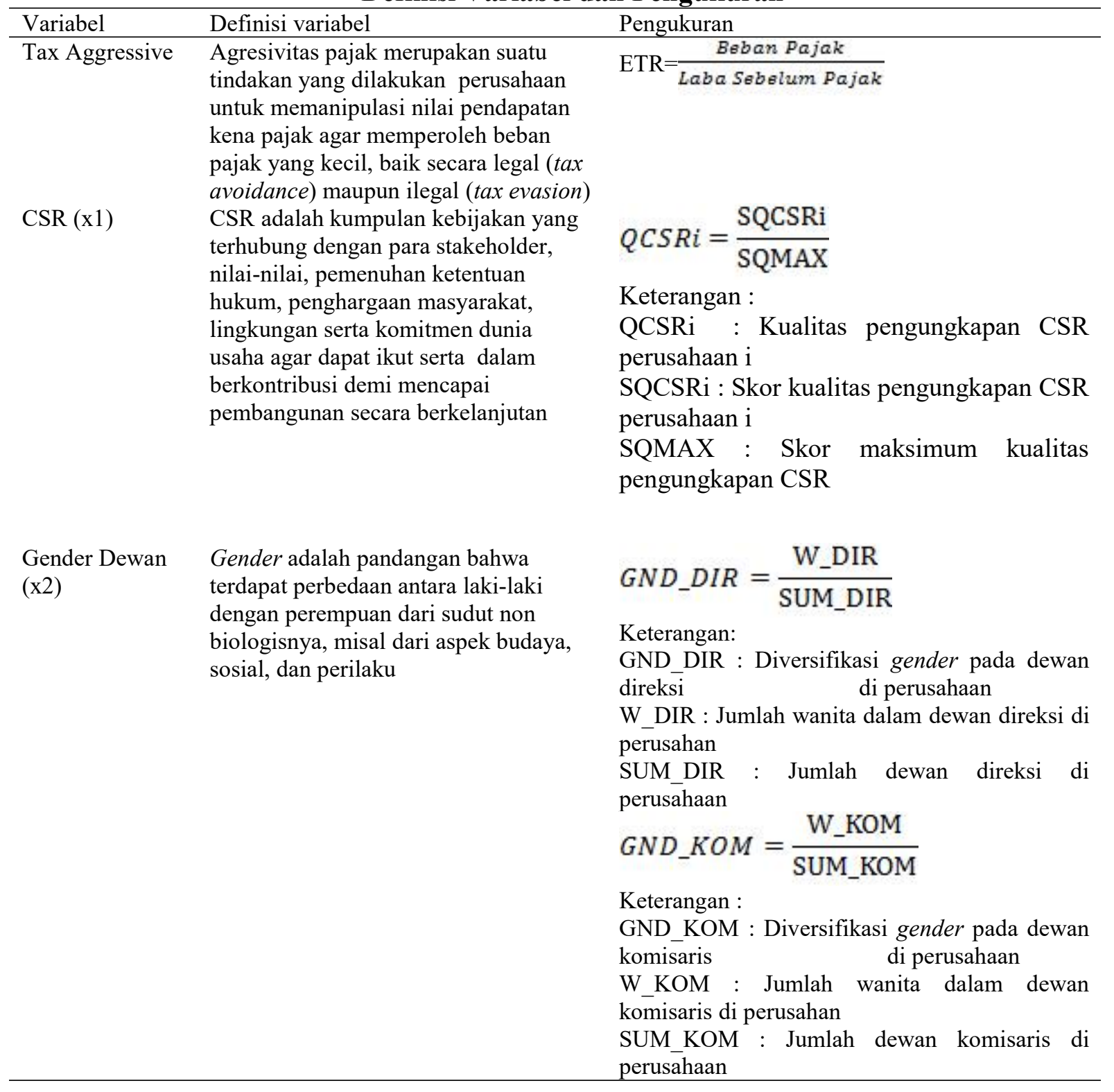

Model Penelitian

Keterangan:

TAit $=\alpha+\beta 1$ QCSRit $+\beta 3$ GND_DIRit $+\beta 4$ GND_KOMit $+\varepsilon i t$

TAit

$\alpha$

$\beta 1, \beta 2, \beta 3, \beta 4$ : Koefisien

QCSRit : Kualitas pengungkapan CSR

GD_DIRit : Gender Dewan Direksi Wanita

GD_KOMit : Gender Dewan Komisaris Wanita

cit : Error Term 


\section{HASIL DAN PEMBAHASAN \\ Statistic deskriptive}

\begin{tabular}{|c|c|c|c|c|c|}
\hline & & $\begin{array}{r}\mathrm{Ta} \\
\text { Statistik } \\
\text { Descripti }\end{array}$ & $\begin{array}{l}\text { el } 3 \\
\text { deskriptif } \\
\text { e Statistics }\end{array}$ & & \\
\hline & $\mathrm{N}$ & Minimum & Maximum & Mean & Std. Deviation \\
\hline$\overline{\mathrm{TA}}$ & 76 & ,01 &, 49 & ,2144 & 09623 \\
\hline QCSR & 76 &, 01 & ,47 & ,2186 & ,09761 \\
\hline GEND_DIREKSI & 76 & 00 &, 75 & , 1257 &, 16250 \\
\hline GEND KOM & 76 & 00 &, 33 & 0758 & ,09645 \\
\hline Valid $\bar{N}$ (listwise) & 76 & & & & \\
\hline
\end{tabular}

Sumber: Output SPSS, olah data 2019

Berdasarkan tabel statistik deskriptif diketahui jumlah observasi penelitian ini adalah sebanyak 76. Hasil analisis variable dependen dengan menggunakan statistik deskriptif terhadap Tax Aggressive menunjukkan nilai minimum tax aggressive adalah 0,01, nilai maksimum tax aggressive adalah sebesar 0,49. Nilai rata-rata dari Tax agrressive perusahaan sebesar 0,2144 dengan standar deviasi 0,09623. Mengartikan bahwa tindakan Tax Aggressive yang paling rendah adalah perusahaan yang ETR perusahaannya berada pada angka $1 \%$ dan perusahaan yang tax aggressive nya tertinggi adalah perusahaan yang ETR perusahaan berada pada angka $49 \%$.

Kualitas pengungkapan CSR dengan nilai terendah (minimum) adalah sebesar 0,01. Nilai CSR tertinggi (maksimum) adalah sebesar 0,47. Nilai rata-rata CSR perusahaan sebesar 0,2186 dengan standar deviasi sebesar 0, 09761. Artinya kualitas pengungkapan CSR yang paling rendah adalah perusahaan yang melaporkan sebesar 1\% dari indikator GRI yang ada dalam laporan keberlanjutan. Sedangkan kualitas pengungkapan CSR perusahaan tertinggi adalah sebesar 47\% dari indikator GRI G4 yang dilaporkan di dalam laporan keberlanjutan. Rata- rata kualitas pegungkapan CSR sebesar $21,86 \%$ dari indikator GRI G4 yang dilaporkan dalam laporan keberlanjutan.

Jumlah gender dewan direksi wanita paling sedikit (minimum) adalah sebesar 0.00, sedangkan jumlah paling banyak (maksimum) sebesar 0,75. Jumlah rata-rata wanita dalam dewan direksi sebanyak 0.1257 dengan standar deviasinya sebanyak 0,16250. Artinya gender dewan direksi wanita yang terendah adalah perusahaan yang tidak memiliki perempuan dalam struktur dewan direksi, sedangkan gender dewan direksi wanita yang tertinggi adalah perusahaan yang $75 \%$ dewan direksinya terdiri dari wanita. Rata-rata perusahaan sampel hanya memiliki gender wanita sebanyak $12.5 \%$ dalam dewan direksi.

Jumlah gender dewan komisaris wanita paling sedikit (minimum) adalah sebesar 0.00 , jumlah paling banyak (maksimum) sebesar 0,33. Jumlah rata-rata wanita dalam dewan komisaris sebanyak 0, 0758 dengan standar deviasinya sebanyak 0, 09645. Artinya gender dewan komisaris wanita yang terendah adalah perusahaan yang tidak memiliki wanita dalam struktur dewan komisaris, sedangkan gender dewan komisaris wanita yang tertinggi adalah perusahaan yang 3.3\% dewan komisarisnya terdiri dari wanita. Rata-rata perusahaan sampel memiliki gender wanita sebanyak 7.5\% wanita dalam dewan komisaris. 


\section{Uji Asumsi Klasik Uji Normalitas}

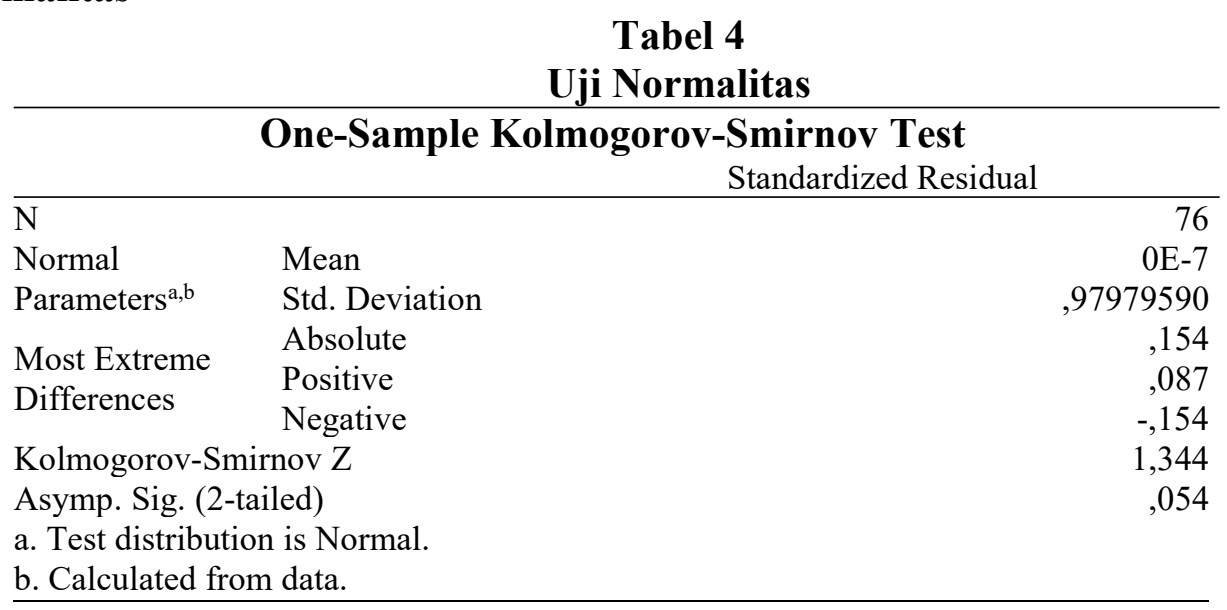

Sumber : Output SPSS, olah data 2019

Dasar pengambilan keputusan dari hasil pengujian normalitas adalah dengan melihat probabilitas Asymp. Sig. (2-tailed). Jika Asymp. Sig. (2-tailed) > 0,05, maka data penelitian dapat dikatakan berdistribusi normal dan sebaliknya. Jika Asymp. Sig. (2-tailed) <0,05, maka data penelitian tidak berdistribusi normal. Berdasarkan hasil uji Kolmogorov-Smirnov pada tabel 5 di atas, dapat diketahui bahwa nilai Asymp. Sig. (2-tailed) adalah sebesar 0,054. Nilai Sig 0,054 lebih besar besar dari 0.05. sehingga dapat dikatakan bahwa data dalam penelitian berdistribusi normal.

\section{Uji Multikoloniaritas}

Tabel 5. Uji Multikoloniaritas Coefficients $^{\text {a }}$

\begin{tabular}{|c|c|c|c|c|c|c|c|}
\hline \multirow[t]{2}{*}{ Model } & \multicolumn{2}{|c|}{$\begin{array}{l}\text { Unstandardized } \\
\text { Coefficients }\end{array}$} & \multirow{2}{*}{$\begin{array}{c}\text { Standardized } \\
\text { Coefficients } \\
\text { Beta }\end{array}$} & \multirow[t]{2}{*}{$\mathrm{T}$} & \multirow[t]{2}{*}{ Sig. } & \multicolumn{2}{|c|}{$\begin{array}{l}\text { Collinearity } \\
\text { Statistics }\end{array}$} \\
\hline & B & $\begin{array}{l}\text { Std. } \\
\text { Error }\end{array}$ & & & & $\begin{array}{c}\text { Tolera } \\
\text { nce }\end{array}$ & VIF \\
\hline (Constant) & ,261 & ,031 & & 8,537 &, 000 & & \\
\hline QCSR &,- 066 & ,112 &,- 067 &,- 591 & ,556 & ,983 & 1,018 \\
\hline $\begin{array}{l}\text { GEND_DIREKS } \\
\text { I }\end{array}$ &,- 088 & ,067 &,- 148 & $-1,314$ & ,193 & ,990 & 1,010 \\
\hline $\begin{array}{l}\text { GEND_KOM } \\
\text { a. } \quad \text { Depender }\end{array}$ & $\begin{array}{r}-, 284 \\
\text { Variable: }\end{array}$ & $\mathrm{TA}^{, 113}$ &,- 285 & $-2,507$ & ,014 & ,975 & 1,026 \\
\hline
\end{tabular}

Sumber : Output SPSS, olah data 2019

Berdasarkan tabel 5, dapat dilihat bahwa nilai VIF untuk variabel QCSR adalah sebesar $1,018<10$, nilai VIF untuk variabel Gend_Direksi adalah sebesar 1,010<10, dan terakhir nilai VIF untuk variabel Gend_Kom adalah sebesar 1,026 juga kecil dari 10. Dari hasil tersebut maka dapat dikatakan bahwa model ini tidak terjadi masalah multikolinearitas. 


\section{Uji Heterokedastisitas}

\begin{tabular}{|c|c|c|c|c|c|c|}
\hline \multicolumn{7}{|c|}{$\begin{array}{c}\text { Tabel 6. Uji Heterokedastisitas } \\
\text { Coefficients }\end{array}$} \\
\hline \multirow{2}{*}{\multicolumn{2}{|c|}{ Model }} & \multicolumn{2}{|c|}{ Unstandardized Coefficients } & \multirow{2}{*}{$\begin{array}{c}\text { Standardized } \\
\text { Coefficients } \\
\text { Beta } \\
\end{array}$} & \multirow[t]{2}{*}{$\mathrm{t}$} & \multirow[t]{2}{*}{ Sig. } \\
\hline & & B & Std. Error & & & \\
\hline \multirow{4}{*}{1} & (Constant) & 050 & ,023 & & 2,199 & ,031 \\
\hline & QCSR & ,072 & ,084 & , 103 & ,864 & ,391 \\
\hline & Gend_DIreksi &,- 019 & ,046 &,- 049 &,- 416 & ,678 \\
\hline & Gend_Kom & ,003 & ,078 & ,004 & ,036 & ,972 \\
\hline
\end{tabular}

Sumber : Output SPSS, olah data 2019

Berdasarkan hasil pengujian pada tabel 6, dapat diketahui bahwa nilai QCSR adalah sebesar 0,391 >0,05, nilai Gend Direksi adalah sebesar 0,678>0,05, dan nilai Gend Kom adalah sebesar $0,972>0,05$. Dari hasil tersebut maka dapat disimpulkan bahwa model regresi tidak mengalami gejala heteroskedastisitas.

\section{Pembahasan hasil penelitian}

\begin{tabular}{|c|c|c|c|c|c|c|}
\hline \multirow{3}{*}{ Model } & \multicolumn{4}{|c|}{$\begin{array}{c}\text { Tabel 7. Uji Signifikan t } \\
\text { Coefficients }^{\mathrm{a}}\end{array}$} & \multirow{3}{*}{$\mathrm{Sig}$} & \\
\hline & Unstandardized & Coefficients & Standardized & $\mathrm{T}$ & & \\
\hline & B & Std. Error & Beta & & & \\
\hline (Constant) & 261 & ,031 & & 8,537 & & ,000 \\
\hline QCSR &,- 066 & ,112 &,- 067 &,- 591 & & ,556 \\
\hline GEND_DIREKSI &,- 088 & 067 &,- 148 & $-1,314$ & & 193 \\
\hline GEND_KOM &,- 284 & ,113 &,- 285 & $-2,507$ & &, 014 \\
\hline
\end{tabular}

a. Dependent Variable: TA

Sumber : Output SPSS, olah data 2019

\section{Hipotesis 1}

Berdasarkan hasil uji signifikan t, membuktikan bahwa kualitas pengungkapan CSR tidak berpengaruh secara signifikan terhadap Tax Aggressive meski arah hubungan yang ditunjukkan adalah negatif. Hasil penelitian ini tidak sejalan dengan penelitiann Sri dan Tjen ( 2016) yang menemukan hubungan negatif antara CSR dengan Tax Aggressive perusahaan. Hasil ini juga belum bisa membuktikan teori stakholder yang memiliki pandangan bahwa perusahaan yang memiliki hubungan baik dengan masyarakat dengan ikut serta dalam program tanggung jawab sosial cendrung tidak melakukan penghindaran pajak.

Namun, penelitian ini mendukung temuan Nusantari, Nuzula dan Darono ( 2015 ), dan makhfudloh (2018) yang juga menemukan hasil tidak berpengaruh secara signifikan antara CSR dengan Tax Aggressive perusahaan. Fenomena ini terjadi kemungkinan besar karna masih rendahnya tingkat pelaksanaan CSR oleh perusahaan sampel. Dari total 76 sampel yang diteliti, rata-rata hanya $23 \%$ perusahaan yang melaksanakan CSR sesuai standar. Kemudian dalam hal pengungkapan, dapat dilihat pada halaman lampiran. Ditemukan bahwa perusahaan yang memperoleh skor 0 pada laporan keberlanjutan perusahaan lebih mendominasi dari skor 3, 2, dan 1. Sehingga dari temuan tersebut dapat diartikan bahwa perusahaan sampel dinilai masih rendah dalam mengungkapkan informasi CSR. 


\section{Hipotesis 2a}

Berdasarkan hasil uji signifikan t, membuktikan bahwa dewan direksi wanita tidak berpengaruh secara signifikan terhadap Tax Aggressive meski arah hubungan yang ditunjukkan adalah negatif. Hasil penelitian ini sejalan dengan penelitian yang dilakukan Oyenike, Olayinka (2018) bahwa keberadaan direktur wanita tidak berpengaruh terhadap aggresivitas pajak.

Penelitian ini tidak sejalan dengan penelitian richardson (2016) yang menyatakan bahwa relatif adanya satu atau lebih keberadaan wanita dalam jajaran dewan direksi akan mampu mengurangi aggresivitas pajak. Dewan Direksi bertanggung jawab atas pengurusan perusahaan sesuai dengan tujuan perusahaan termasuk dalam hal pengambilan keputusan terkait agresifitas pajak. Menurut Ricardson (2016) hadirnya wanita dalam dewan direksi dapat mengurangii agresivitas pajak perusahaan dikarnakan wanita memiliki standar etika dan moral yang lebih tinggi serta dinilai lebih menghindari resiko dibanding pria.

Namun, berdasar pada hasil penelitian ini yang menguji terhadap perusahaan yang listing di BEI dan menerbitkan Sustainable report secara berurut menemukan hasil bahwa hadirnya wanita dalam jajaran dewan meskipun menunjukkan arah yang negatif, tidak memiliki pengaruh yang signifikan terhadap agresivitas pajak. Hal ini mungkin terjadi dikaitkan dengan fakta bahwa beberapa wanita yang berada dalam jajaran dewan direksi tidak memadai untuk mendorong manfaat perbedaan gender yang diharapkan atas kebijakan aggresifitas pajak.

Oyenike dan olayinka (2018) berpendapat bahwa ketidakmampuan direksi wanita dalam meredam tindakan agresifitas pajak berasal dari kurangnya perwakilan dan ketidakcukupan wanita profesional di posisi manajemen senior. Menurut penelitian Internasional Finance Corporation (IFC) yang berjudul keanekaragaman Gender Dewan Perusahaan di ASEAN, Indonesia tertinggal dalam hal jumlah perempuan yang menduduki posisi manajemen senior $(18,4 \%)$ jauh di bawah rata-rata ASEAN yakni $25,2 \%$. Hal tersebut mungkin menjadi alasan bagi direksi wanita untuk tidak signifikan dalam memininimalkan prilaku agresifitas pajak. Akibatnya, proporsi wanita yang duduk di jajaran dewan tidak cukup memadai untuk memberikan pengaruh terhadap pengambilan keputuasan terkait kebijakan pajak. Oyenike dan Olayinka (2018) dalam penelitiannya juga berpendapat bahwa keberadaan dewan wanita dalam jajaran dewan direksi hanya sebagai upaya bagi perusahaan dalam meningkatkan keanekaragaman gender dewan untuk memenuhi peningkatan dukungan akan keanekaragaman ruang dewan.

\section{Hipotesis 2b}

Berdasarkan hasil uji signifikan t, membuktikan bahwa dewan komisaris wanita berpengaruh negatif dan signifikan terhadap Tax Aggressive perusahaan dengan tingkat signifikansi sebesar 0,009 , artinya kenaikan $1 \%$ proporsi perempuan dalam dewan komisaris di perusahaan akan menurunkan tindakan Tax Aggresive perusahaan sebesar 0,303. Hasil tersebut mendukung hipotesis 2b. Hal ini berarti bahwa Tax Aggressive perusahaan akan menurun ketika proporsi perempuan dalam jajaran dewan komisaris perusahaan meningkat.

Penelitian ini tidak sejalan dengan penelitian yang dilakukan oleh Gunawan (2018) yang menjelaskan tidak ada pengaruh keberagaman gender dewan komisaris terhadap aggressive tax planning yang diukur menggunakan ETR perusahaan. Hal tersebut dikarenakan masih adanya fenomena glass ceiling yang terjadi di Indonesia, pria cenderung mendominasi pekerjaanpekerjaan di tingkat top management sedangkan wanita dijadikan sebagai kaum minoritas.

Tugas utama dari dewan komisaris adalah untuk mengawasi kebijakan direksi dalam menjalankan perseroan serta memberikan nasihat kepada direksi (pasal 108 ayat 1 dan 2 UU 40 
th 2007). Dalam hal ini dewan komisaris akan mengawasi dan mengontrol direksi agar tetap menghasilkan kinerja yang baik salah satunya adalah dengan tidak melakukan agresifitas pajak perusahaan yang akan beresiko terhadap perusahaan. Penelitiaan ini berhasil membuktikan bahwa dewan komisaris wanita berpengaruh negatif terhadap tindakan aggresifitas pajak perusahaan.

Hadirnya wanita dalam jajaran dewan komisaris dinilai membantu dalam meningkatkan pengawasan yang intensif terhadap tindakan pengurusan perusahaan. Karna wanita memiliki sikap kehati-hatian yang sangat tinggi, cendrung menghindari resiko dan dinilai lebih teliti dibanding pria. Sifat risk averse pada wanita membuat wanita mengambil keputusan yang berisiko lebih rendah sehingga akan mampu mengurangi tingkat agresivitas pajak (Kusumawati, 2007). Terkait dengan hasil penelitian yang dilakukan terhadap perusahaan sampel. Dengan rata-rata $1 \%$ atas proporsi wanita dalam dewan komisaris, mampu membuktikan bahwa gender dewan komisaris wanita berpengaruh negatif dan signifikan terhadap agresivitas pajak (tax aggressive).

\section{SIMPULAN, KETERBATASAN DAN SARAN \\ Simpulan}

Tujuan penelitian ini adalah untuk membuktikan bagaimana pengaruh dari kualitas pengungkapan CSR, dewan direksi wanita dan dewan komisaris wanita terhadap tax Aggressive dengan uji regresi berganda menggunakan aplikasi SPSS. Pengujian dilakukan dengan cara melakukan uji terhadap 76 observasi pada perusahaan yang terdaftar di BEI selama tahun 20152018 yang melaporkan laporan tahunan dan laporan keberlanjutan selama 4 tahun secara berturut- turut. Hasil penelitian adalah sebagai berikut :

1. Kualitas pengungkapan CSR berpengaruh negatif dan tidak signifikan terhadap Tax Aggressive pada perusahaan yang terdaftar di BEI selama periode 2015- 2018.

2. Dewan direksi wanita berpengaruh negatif dan tidak signifikan terhadap Tax Aggressive pada perusahaan yang terdaftar di BEI selama periode 2015- 2018.

3. Dewan komisaris wanita berpengaruh negatif dan signifikan terhadap Tax Aggressive pada perusahaan yang terdaftar di BEI selama periode 2015- 2018.

\section{Keterbatasan}

1. Nilai adjusted $R^{2}$ adalah 0,078 yang berarti bahwa kontribusi variabel independen hanya sebesar 0,078 atau 7,8\% sehingga masih banyak variabel lain yang mempengaruhi Tax Aggressive.

2. Sumber informasi CSR yang digunakan dalam penelitian hanya berasal dari laporan keberlanjutan perusahaan sehingga tidak semua indikator CSR pada GRI diungkapkan dengan jelas.

3. Sampel penelitian tidak mengklasifikasikan sektor industrinya hanya melihat pada perusahaan yang menerbitkan laporan keberlanjutan.

4. Teknik pengambilan sampel memakai purposive sampling hanya memperoleh 19 perusahaan yang menjadi sampel.

\section{Saran}

Berdasarkan keterbatasan penelitian yang telah disampaikan adapun saran yang diberikan:

1. Penelitian selanjutnya sebaiknya menambah variabel lain yang dapat mempengaruhi Tax Aggressive karena nilai adjusted $R^{2}$ yang diperoleh hanya sebesar 7,8 \% 
2. Penelitian selanjutnya, lebih baik berfokus pada satu sektor perusahaan agar memperoleh hasil uji yang lebih baik.

\section{DAFTAR PUSTAKA}

Anggraeni, Dian Yuni dan Chaerul D. Djakman. (2017). Slack Resources, Feminisme Dewan dan Kualitas Pengungkapan Tanggung Jawab Sosial Perusahaan. Jurnal Akuntansi dan Keuangan Indonesia, 14(1): 94 - 118.

Ardyansyah, Danis., Zulaikha. (2014). Pengaruh Size, Leverage, Profitability, Capital Intensity Ratio Dan Komisaris Independen Terhadap Effective Tax Rate (Etr). Semarang: Fakultas Ekonomika dan Bisnis Universitas Diponegoro.

Centre for Governance, Institutions and Organisations (CGIO). 2012. Indonesia Boardroom: Diversity Report 2012, Female Footprints in IDX-Listed Companies. Singapore: National University of Singapore NUS Business School.

Frank, M.M., Lynch, L.J., Rego, S.O. (2009). Tax Reporting Aggresivenes and its Relation to Aggresive Financial Reporting. Social Science Research Network, 84 (2), 467- 496.

Gunawan, E.V. dan sulistiawan. (2018). Pengaruh Karakteristik Dewan Komisaris terhadap Aggressive Tax Planning. Jurnal Ilmiah Mahasiswa Universitas Surabaya, 7(1).

Huseynov, Klamm. (2012). Tax Avoidance, Tax Management, And . Corporate Social Responsibility. Journal of Corporate Finance, 18. 804-827

Jensen \& Meckling, 1976, The Teory Of The Firm : Manajerial Behavior, Agency Cost, and Ownership Structure, Journal of Financial And Economics, 3; 305- 360

Lanis,R. And G. Richardson. (2011). Corporate Social Responsibility and tax Aggresivenes: An Empirical Analisis. J Account. Public Policy, 86-108

Lanis,R. And G. Richardson. (2015). Corporate Social Responsibility Performance Associated with Tax Avoidance?. Journal Bus Ethics 127 : 439- 457

Makhfudlah, F., Herawati, N., Wulandari, A. (2018). Pengaruh CSR Terhadap Perencanaan Agresivitas Pajak, Jurnal Akuntansi dan Bisnis. 18(1), 48- 60

Martani, S. D. (2010). Karakteristik Kepemilikan Perusahaan, Corporate Governance dan Tindakan Pajak Agresive. Jurnal Akuntansi, 1 - 32.

Oyenike, O., \& Olayinka, E. (2016). Female Directors and Tax Aggressiveness of Listed Banks in Nigeria. The 3rd International Conference on African Development Issues, ISSN:2449-, 293-299.

Pradnyadari. (2015). Pengaruh Pengungkapan Corporate Social Responsibility terhadap Agresivitas Pajak Perusahaan pada Perusahaan Manufaktur yang Terdaftar di BEI tahun 2011- 2013. Universitas Diponegoro

Rahayu. (2016). Pengaruh Kompensasi Eksekutif, Keterwakilan CFO wanita dan Karakteristik Eksekutif terhadap Tindakan Pajak Agresif.

Rizky, A. F. (2017). Pengaruh Pengungkapan Corporate Social Responsibility terhadap Aggresivitas Pajak. Jurnal Akuntansi Universitas Widyatama .

Sari, Dewi Kartika dan Dwi Martani. (2010). Karakteristik Kepemilikan Perusahaan, Corporate Governance, dsn Tindakan Pajak Agresif. Jurnal Akuntansi. 1- 32. 